\title{
Iranian EFL learners' and teachers' perceptions of good and poor language learners: Points of convergence and divergence
}

\author{
Tamimi Sa'd, Seyyed Hatam $\varangle$ \\ Urmia University, Iran (Shtamimi90@gmail.com) \\ Gholami, Javad \\ Urmia University, Iran (j.gholami@gmail.com)
}

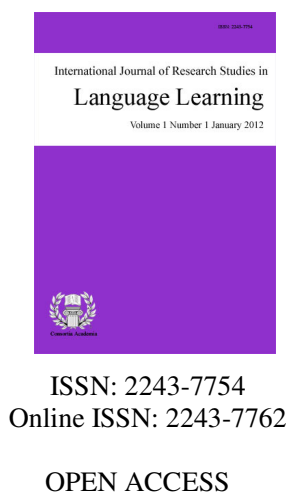

Received: 25 October 2013

Revised: 22 January 2014

Available Online: 15 March 2014

DOI: $10.5861 /$ ijrsll.2014.660

Accepted: 25 January 2014

\section{Abstract}

This qualitative study is an investigation into Iranian EFL teachers' and learners' perceptions of good and poor language learners with an eye on where the beliefs of these two groups coincide or diverge. The study was an attempt to scrutinize the most commonly held beliefs on successful and unsuccessful language learners by EFL teachers and learners. To this end, a total number of 110 elementary EFL learners (95 males and 15 females) and 20 male language teachers, aged between 26 and 45, with 2 to 13 years of English teaching experience were asked to verbalize their perceptions through describing what they perceived as good and poor language learners. General, common trends and themes as well as dissimilarities were found in the features mentioned by the teachers and learners for good and poor language learners. The results revealed that the teachers' viewpoints revolved mainly around the communicative ability of the successful language learners outside the classroom milieu while the learners' viewpoints were found to be more traditional in nature, emphasizing the teacher's authority, and the learners' discipline inside the classroom setting and their steady practice as the main criteria to distinguish between good and poor language learners. The findings clearly indicated that, at times, the learners' perceptions of (un)successful language learners stand in contrast to, i.e., diverge from, their teachers'. In conclusion, this mismatch can have serious negative connotations on the learning behavior of the learners in the long run. Therefore, language teachers are expected to improve the learners' perceptions of successful language learning and of what it means to be a successful language learner.

Keywords: good language learners; poor language learners; EFL teachers; EFL Learners; perceptions 


\section{Iranian EFL learners' and teachers' perceptions of good and poor language learners: Points of convergence and divergence}

\section{Introduction}

The ultimate goal of language teaching might be, perhaps, to train language learners who, while possessing both accuracy and fluency, are successful in language learning once viewed from various perspectives, from grammatical ability to lexical knowledge to communicative competence, among others. More often than not, virtually in every language learning situation some learners are seen to excel their peers academically, communicatively, and linguistically. An understanding of these successful learners and of the key to their success and subsequently the conveying of this awareness to the un- or less successful learners has for long fascinated a large number of researchers (Maftoon, Daftari, \& Lavasani, 2011; Naiman, Fröhlich, Stern, \& Toedesco, 1978; Norton \& Toohey, 2001; Rubin, 1975).

In effect, the idea is that by investigating the successful language learners, identifying their characteristics, and finally applying and strengthening these characteristics among the 'poor' language learners, second/foreign language researchers as well as teachers can afford their students with the key to success in their language learning process (Rubin, 1975). Thus, the past few decades have witnessed a myriad of research studies carried out in various contexts, from Western to Eastern, to investigate and figure out the mystery behind the astonishing achievement of some learners who have been labeled "good language learners" (Alves, 2008; Ho, 2011; Maftoon et al., 2011; Naiman, et al, 1978; Norton et al., 2001; Takeuchi, 2008).

A glance at the work on EFL teachers and learners' views and perceptions concerning what a successful and unsuccessful language learner means to them indicates that very few, if any, studies have been conducted in this regard. The current qualitative study attempts to deeply delve into the perceptions of successful and unsuccessful language learners as voiced by language teachers and learners.

\subsection{Background}

The idea of good language learner (GLL) commanded wide assent in the 1970's and quite a large number of studies have paved the way to understanding these learners from diverse perspectives and unraveling their characteristics. In this connection, a good language learner is defined in terms of the characteristics s/he is associated with. The research on GLLs was first undertaken in the OISE Modern Language Centre in Toronto, Canada by Stern. This project was based on the learning strategies and processes employed by GLLs (Stern, 1990). Other studies (Fröhlich, 1976; Naiman et al., 1978) revealed that these successful learners were unanimously identified with such characteristics as: taking advantage of potentially useful learning situations, creating them, developing learning techniques and strategies appropriate to their individual needs.

According to Rubin (1975), GLLs are (1) willing and accurate guessers, comfortable with uncertainty, (2) having a strong desire to communicate, (3) not inhibited by uncertainty, (4) focusing on both communication and form, (5) doing a lot of practice with the language components like pronunciation, (6) monitoring one's own and others' speech, and (7) paying attention to the meaning, context, and mood of the speech. Rubin implies that research on and the teaching of learning strategies to unsuccessful language learners would assist them in language, hence the concept of strategy instruction. Taking advantage of the learners' own self-assessment, their performance on language proficiency measures, and their teachers' recommendations as the criteria to select GLLs, Norton \& Toohey (2001) conducted a study which, in the authors' terms, focused on the "learners' internal characteristics, learning strategies, or linguistic outputs, but also on the reception of their actions in particular sociocultural communities" (p. 308). They deduced that GLLs' success is justifiable "on the basis of their access to a variety of conversations in their communities rather than on the basis of their control of a wider 
variety of linguistic forms or meaning than their peers or on the basis of their speed of acquisition of linguistic forms and meanings (p. 310)".

Alves (2008) summarized the features of effective learners as follows: having a need or desire to learn English, being determined and persistent in language learning, measuring their progress in stages, enjoying encountering the language outside the classroom, being unafraid of making mistakes but learning from them, etc. She concluded that owing to the diversity of ways of language learning, a language pedagogy catering for the multiple intelligences is to be established to enhance various individuals' learning capabilities. In a case study of two successful Iranian language learners, Amiri and Baghchejoughi (2011) took into account the learners' personality features and strategies, finding that successful language learners are: tolerant, extrovert, responsible for their own learning, intuitionists, feeling type, mostly perceiving, etc. They reached the conclusion that there seems to be a high correlation between good language learning and further social and educational progress.

GLLs have also been investigated from other perspectives. The relationship between multiple intelligences and language learning strategies, for instance, was investigated by Akbari and Hosseini (2008). Results showed that there was a significant correlation between the use of L2 learning strategies and learners' MI scores on MIDAS, a commercially designed instrument used to measure the participants' multiple intelligences scores, with the conclusion that "successful language learning involves conscious planning and storage of L2 data" ( $\mathrm{p}$. 15).

Maftoon et al. (2011) examined GLLs from autonomy perspective, group cohesiveness, and group norm, and found that these learners were all autonomous and more observant of the class norms rather than group cohesiveness. They inferred that GLLs differed from poor language learners in terms of the subcategories of autonomy. The study unraveled that GLLs are considerate of the standards, rules, and generally norms of the class (e. g., coming to the class on time, helping their peers, getting prepared before the class, etc.).

Chamot and Rubin (1994, as cited in Dörnyei, 2005, p. 163) posited that, "the good language learner cannot be described in terms of a single set of strategies but rather through the ability to understand and develop a personal set of effective strategies".

In spite of the large number of studies on GLLs carried out from various perspectives including learning strategies and styles, personality features and characteristics, vocabulary learning (Gu, 2003), motivation, learning autonomy, and recently sociocultural communities, among others, few studies, if any, have examined successful and unsuccessful language learners from the perspective of the attitudes held by the Iranian language teachers and learners. Therefore, by uncovering these attitudes, the present study aims at unraveling the possible ways of language learning prevalent among Iranian EFL learners since attitudes do impact on the approach that learners adopt towards learning an L2.

\subsection{Research questions}

Without a doubt, a good knowledge of EFL teachers' and learners' beliefs about the various elements involved in educational contexts can help foster our endeavor in achieving our pedagogical purposes. Thus, the present study set out to find answers to the following research questions:

$>\quad$ RQ1. What are the most important characteristics of good language learners from Iranian EFL teachers' viewpoints?

$>$ RQ2. What are the most important characteristics of poor language learners from Iranian EFL teachers' viewpoints?

$>$ RQ3. What are the most important characteristics of good language learners from Iranian EFL learners' viewpoints? 
Tamimi Sa'd, S. H. \& Gholami, J.

$>\quad$ RQ4. What are the most important characteristics of poor language learners from Iranian EFL learners' viewpoints?

\section{Method}

\subsection{Participants}

The participants consisted of 110 beginner EFL learners ( 95 males and 15 females), aged between 13 and 17 and 20 language teachers, aged between 26 and 45, only males. At the time of the study, they were attending and teaching at various language institutes in Tabriz, Urmia and Ahvaz. Regarding, their language background, they spoke Turkish, Arabic and Persian.

\subsection{Instruments}

To collect the data, the researchers employed an open-ended questionnaire that consisted of two questions which required the participants to voice their perceptions of what features successful and unsuccessful language learners possess. The participants were asked to define successful and unsuccessful language learners in general terms and avoid going into details. They were also asked to avoid giving technical explanations and instead try to offer their viewpoints in their own language.

\subsection{Procedure and data analysis}

The participants, both language learners attending various language institutes in Tabriz, Urmia and Ahvaz at the time of the study and teachers teaching at these institutes, were asked to reply to an open-ended questionnaire, mentioning, in their viewpoints, the most important characteristics that successful and unsuccessful language learners mostly possess. The researchers did not provide the participants with any hints or clues as to who is labeled a successful or unsuccessful language learner lest that this may affect their perceptions.

To collect the most widespread characteristics of successful and unsuccessful language learners, the researchers analyzed the responses with regard to the most recurring features mentioned in the responses as the criteria according to which to distinguish between good and poor language learners.

\section{Results}

\subsection{Findings of the study}

This study was carried out as an attempt to inquire into the perceptions of Iranian EFL teachers and learners of successful and unsuccessful (here termed good and poor) language learners. Results show relative coincidence as to how EFL teachers and learners perceive good and poor language learners. These findings are presented below with the hope that the research questions set above are answered one by one. Some of the responses provided by the teachers and learners are offered for better analysis.

Good language learners: Teachers' viewpoints - The first research question dealt with the most important characteristics of good language learners from Iranian EFL teachers' viewpoints. For better understanding, some of the teachers' responses have been transcribed below. The results have been summarized in Table 1.

1. A successful language learner is both fluent and accurate. S/he can speak easily and can make $\mathrm{him} / \mathrm{herself}$ understood very easily in the target language.

2. In my way of thinking, such learners can communicate in the target language and can transfer their knowledge from the classroom to settings outside the class. 
3. They practice on a regular basis and are disciplined in the classroom. They also have respect for their classmates and teachers.

4. These learners know a large number of vocabulary items and observe the grammatical rules quite often.

The analysis of the teachers' views of good language learners showed that their responses consisted mainly of the following three categories offered in Table 1.

Table 1

Characteristics of Good Language Learners from EFL Teachers' Viewpoints (N=20)

\begin{tabular}{lcc}
\hline \multicolumn{1}{c}{ Characteristics } & Frequency & Percent \\
\hline The ability to transfer class knowledge to outside-the-class settings & 13 & 65 \\
Steady effort to learn the target language; an extensive repertoire of vocabulary; & 7 & 35 \\
A good command of spoken English; & 5 & 25 \\
A balanced command of both fluency and accuracy & 5 \\
\hline $\begin{array}{l}\text { Note. The majority of the characteristics mentioned were found to be common among most participants and hence each percentage for each } \\
\text { of the sections of the table above has been calculated out of } 100 .\end{array}$
\end{tabular}

The teachers mentioned steady practice and effort as well as perseverance in learning the target language as the other characteristics of successful language learners. These characteristics were highlighted by the learners too (see text to come).

Poor language learners: Teachers' viewpoints - The next research question addressed the issue of Iranian EFL teachers' perceptions of poor language learners.

Iranian EFL teachers mentioned the following as the features of poor or unsuccessful language learners summarized in Table 2 .

\section{Table 2}

Characteristics of Poor Language Learners from EFL Teachers' Viewpoints $(N=20)$

\begin{tabular}{lcc}
\multicolumn{1}{c}{ Characteristics } & Frequency & Percent \\
\hline Not learning a language communicatively, but as an institute course to be passed; & 16 & 80 \\
Mere obsession with grades & & \\
Lack of perseverance and interest in the target language & 13 & 65 \\
Lack of enough activity and motivation & 9 & 45 \\
Poor speaking abilities & 6 & 35 \\
Frequent skipping of classes and assignments & 4 & 20 \\
\hline
\end{tabular}

Note. The majority of the characteristics mentioned were found to be common among most participants and hence each percentage for each of the sections of the table above has been calculated out of 100 .

Interestingly enough, the results above suggested that the teachers' perceptions of poor language learners were found to stand in contrast with the learners' in the case of communicative inability and in line with the learners' when lack of study, effort and practice were concerned. The responses below reflect the above characteristics:

5. Such language learners lack discipline in class and does not respect their classmates or teachers.

6. I think these learners have no schedule for learning English. They don't practice regularly and aren't interested in learning English.

7. They rarely attend to their teacher, skip classes frequently and are irresponsible for what they do or for what's going on in the classroom.

8. Unsuccessful language learners do not persevere to learn the target language. Their speaking abilities 
Tamimi Sa'd, S. H. \& Gholami, J.

and their memory are very poor.

Good language learners: Learners' viewpoints - In addition to teachers' viewpoints regarding successful language learners, those of EFL learners were also taken into consideration. Table 3 summarizes the characteristics that learners mentioned for good language learners.

\section{Table 3}

Characteristics of Good Language Learners from EFL Learners' Viewpoints (N=110)

\begin{tabular}{lcc}
\hline \multicolumn{1}{c}{ Characteristics } & Frequency & Percent \\
\hline $\begin{array}{l}\text { Inside-the-class discipline (including respect for teacher, peers, regular attendance in } \\
\text { class, punctuality, doing assignments, attention, politeness, etc.) }\end{array}$ & 538.2 \\
$\begin{array}{l}\text { Steady practice, effort and perseverance in FL learning } \\
\text { Personality variables (including asking a lot of questions, attention and concentration, } \\
\text { ability to answer teacher's or peers; questions, good speaking, memorization, } \\
\text { pronunciation abilities, much use of FL, etc.) }\end{array}$ & 49 & 44.5 \\
$\begin{array}{l}\text { Outside-the-class discipline (including having a schedule in learning FL, time } \\
\text { management, study of extracurricular materials, doing homework, etc.) }\end{array}$ & 42.8 \\
$\begin{array}{l}\text { Other (having a purpose in FL learning, good scores, having a good teacher, etc.) } \\
\text { Note. The majority of the characteristics mentioned in this table were found to be common among most participants at the same time and } \\
\text { hence each percentage for each of the sections of the table above has been calculated out of 100. }\end{array}$ & 219.1 \\
\hline
\end{tabular}

Some of the learners' responses in this regard are presented below:

9. I think a good language learner studies regularly, participates actively in class activities and is not lazy.

10. A successful language learner speaks English very fluently and can easily communicate with other learners.

11. Such learners can learn a language by themselves and are very keen on travelling to English-speaking countries.

12. Such a learner is studious, disciplined, and polite in class and listens to his teacher.

Poor language learners: Learners' viewpoints - The fourth research question addressed the most important characteristics of poor language learners from Iranian EFL learners' viewpoints. The results of this section are summed up in Table 4 below.

\section{Table 4}

Characteristics of Poor Language Learners from EFL Learners' Viewpoints $(N=110)$

\begin{tabular}{lcc}
\hline \multicolumn{1}{c}{ Characteristics } & Frequency & Percent \\
\hline $\begin{array}{l}\text { Lack of regular study, practice, and effort; Laziness; lack of class activity, enthusiasm } \\
\text { and politeness; lack of schedule in learning the target language; not doing assignment } \\
\text { or homework }\end{array}$ & 48 & 43.7 \\
Lack of discipline in class; no attention to the teacher; lack of concentration & 43 & 39.1 \\
& 17 & 15.4 \\
& 10 & 9.1 \\
$\begin{array}{l}\text { lack of interest in the target language } \\
\text { Poor speaking and listening abilities; Poor communicative abilities; poor memory, } \\
\text { among others }\end{array}$ & & \\
\hline $\begin{array}{l}\text { Note. The majority of the characteristics mentioned in this table were found to be common among most participants at the same time and } \\
\text { hence each percentage for each of the sections of the table above has been calculated out of 100. }\end{array}$
\end{tabular}

The above-mentioned characteristics of poor language learners are reflected in the following transcriptions:

13. An unsuccessful language learner is lazy, inactive in class and impolite, shows no respect for other learners and for his teacher, and does not attend to his teacher. 
14. An unsuccessful language learner is not interested in learning English.

15. Such learners do not practice English at home, don't listen to their teachers in class and don't have a good schedule for language learning.

16. He is always frustrated in class and can't enjoy learning a language.

\subsection{Discussion}

What follows is a discussion of the results obtained. The discussion is done in light of the previously conducted studies. Thus, it is hoped that this will shed some light on the similarities as well as the differences among the teachers' and learners' perceptions of successful and unsuccessful language learners.

Good Language Learners: Teachers'versus Learners'viewpoints - The teacher participants consisted of 20 EFL teachers with various years of teaching experience ranging from 2 to 13. As can be seen from Tables 1 and 2 , the teachers mentioned a variety of features for successful and unsuccessful language learners. These features can be classified according to the occurring themes prevalent in the responses. For example, the teachers' assertion that successful learners are able to transfer their language knowledge from the classroom settings to outside-the-class settings (i.e., natural settings) is suggestive of the teachers' obsession with the pragmatic ability of the learners. This characteristic was mentioned by the majority of the teachers but by a small number of learners (see Table 3).

Steady effort and practice in language learning was the second most frequently cited feature of successful learners. This result is in line with Rubin (1975) who posited that successful learners do a lot of practice with the language components such as pronunciation and vocabulary. The results are also in line with Amiri and Baghchejoughi's (2011) study results.

On the plus side, the results indicated that possessing a balanced command of both fluency and accuracy was believed by the teachers to be one of the features of successful learners. This finding is also consistent with Rubin (1975) who found that GLLs focused on both communication and form. The students mentioned that motivation, interest in the target language and having a good memory are among the prevailing characteristics of GLLs. These features have been found to be true in other contexts as well. For instance, Morales and Smith (2008) demonstrated that students of Spanish rely on memorization, mental images and self-motivation as their strategies in language earning.

The learners also enumerated some features of successful language learners. As can be seen from Table 3, the characteristics that participants mentioned for successful language learners that can be classified into some categories, for example, discipline inside and outside the language classroom, characteristics related to the learner's personality such as asking a lot of questions, attention and concentration, among others. These findings are in line with some studies previously done by other scholars. For instance, similarly, in a study of what he termed 'good foreign language learners', Takeuchi (2008) indicated that regular practice and increasing vocabulary repertoire, which are among the strategies mentioned by the learners in the present study, constitute two of the strategies that beginner and intermediate Japanese 'good' EFL learners had reported to use in their language learning. According to Takeuchi (2008), the fact that some specific strategies were reported by learners in specific stages of language learning indicates that "More attention, therefore, should be paid to the concept of the stages of learning in the future research on strategies" (p. 391).

To some extent, Takeuchi's findings, therefore, overlap with those obtained here. This overlapping manifests itself more in the fact that both Iranian EFL learners and beginner and intermediate Japanese learners mentioned what seem to be accuracy and fluency-related features as inevitable features of good language learners. The next feature that was mentioned by the participants was the issue of discipline. This area was not reported by Takeuchi (2008). This might be suggestive of the fact that Iranian EFL learners had envisioned what they viewed 
as successful learners more broadly by stating even those features that might not be directly related to the enterprise of language learning, for example, discipline characteristics. It is noteworthy that, following Rubin (1975, p. 43), by strategies are meant "the techniques or devices which a learner may use to acquire knowledge".

Likewise and quite in line with the teachers' viewpoints, the learners' emphasis on discipline as one of the most important features of successful language learners was already corroborated by Maftoon et al. (2011). In their study of the good language learners, Maftoon et al. (2011) demonstrated that, apart from other characteristics, such learners "showed to be considerate of the standards, rules and generally norms of the class" (p. 11).

The teachers also mentioned other features which can rarely be found in the literature. These features relate mainly not to the cognitive or social levels of language learning but to the linguistic level including an extensive repertoire of vocabulary and a good command of spoken English. Therefore, the features cited in the literature on what constituted successful language learners are cognitive or metacognitive, such as being not inhibited by uncertainty or monitoring one's progress as pointed out by Rubin (1975) or more recently by Alves (2008), the characteristics enumerated by Iranian EFL teachers were of a linguistic level. What is more, the teachers' emphasis on the successful learners' ability to transfer their classroom language knowledge to outside-the-class settings shows the teachers' obsession with the pragmatic ability and function of their learners. The interesting point is that the language learners did not mention this characteristic which may be indicative of their primary obsession with language at the structural level (i.e., vocabulary, pronunciation, grammar, etc.).

Poor Language Learners: Teachers' versus Learners' viewpoints - The teachers' mentioning of lack of interest in the target language as one of the major features of poor language learners is in line with Alves (2008). Alves argued that GLLs have a need or desire to learn English which implies that poor learners do not possess this feature. As can be seen from Tables 2 and 4, there can be seen a consensus between the teachers and learners in their emphasis on the poor learners' lack of interest in the target language, the feature that was reported by both groups to belong to the successful language learners.

The persistent feature of the responses provided by the learners was their emphasis on the characteristics of good and poor language learners that can be organized around a number of themes as done in Tables 3 and 4 . These themes are as follows:

1. Characteristics relating to the classroom setting (e.g., discipline, regular class attendance, etc.)

2. Characteristics relating to the linguistic matters (e.g., proficiency, vocabulary, etc.)

3. Characteristics relating to personality (e.g., attention, frequent use of target language, etc.)

Taking into account these characteristics, we can assume that these reflect the effect of the institutional regulations and rules. For instance, the repeated insistence on regular class attendance and discipline, whether inside or outside the class, shows the learners' preoccupation with these matters. Interestingly enough, institutional issues such as those mentioned by the learners were not of considerable importance to the teachers and instead it was the linguistic matters that were rated as significant. It was constantly found that while the learners reported discipline as the necessary feature that successful language learners possess and that the unsuccessful ones are lacking in, this area was of no interest to the teachers in this study. This indicates the discrepancy between the views of the two groups which may result in differing ways of viewing the task of language learning by teachers and learners.

The findings support those obtained by other researchers. For instance, the emphasis on doing regular practice, class attendance and discipline which were found to be the overriding characteristics mentioned for good language learners in this study were already corroborated by Amiri and Baghchejoughi (2011). They asserted that, for example, GLLs were said to enjoy characteristics such as interest in speaking in the target language and the ability to use it in a variety of contexts. 
Furthermore, the fact that linguistic structures were a high priority to the language learners contrasts Norton and Toohey's (2001) findings whose study confirmed that their 'good' language learners did not focus on the language structures per se and "sought to set up counter-discourses in which their identities could be respected and their resources valued, thereby enhancing the possibilities for shared conversation" (p. 318). Implied in this statement is the possibility on the part of the learners to lose the opportunities of 'shared conversation' by focusing solely on the language structures. In a sense, therefore, the perceptions of Iranian EFL teachers and learners can be said to be complementary in part; that is, their perceptions in this regard converge on some issues but diverge in others.

Another feature mentioned by both Iranian EFL teachers and learners was motivation and interest in the target language. The participants held that successful language learners possess this characteristic and that unsuccessful ones lacked it. This finding supports Rubin's (1975) finding in this regard. Rubin (1975) further goes on to state that the issue of motivation is not contentious, contending that "The problem is how to provide the necessary motivation for others within the school framework-if that is possible" (p. 43). This really proves a thorny problem for the language teacher, particularly the EFL one who is considerably removed from the native speaker environment and should motivate his/her students in an EFL context. Rubin further concludes that "With proper motivation, the learner may become an active investigator of the nature of the language to be learned" (p. 43).

In general, a comparison of the features mentioned by the teachers and learners and the number of these features confirms the feature of successful language learners that has been recurrently stated in the literature: frequent use of various learning strategies (Halbakh, 2000). Furthermore, it has been argued that unlike unsuccessful language learners, successful learners employ these strategies not only frequently but also appropriately (Rubin, 1975).

\section{Conclusion and implications}

A good knowledge of EFL teachers' and learners' beliefs about the various elements involved in educational contexts, here their viewpoints concerning the successful and unsuccessful language learners, can help foster our endeavor in achieving our pedagogical purposes. Since teachers are one of the main sources that EFL learners can benefit from to improve their understanding concerning who is to be labeled successful or unsuccessful language learner, teachers are expected to enhance the learners' knowledge in this regard. Many researchers have called for recognizing and aknowledging teachers (Kuhi \& Abdolvash, 2014). Likewise, Amiri and Baghchejoughi (2011) have specified that understanding good language learners can be of benefit in that "the potential for learner training can be explored and teachers can approach their students with helpful well designed tasks to help their students become better language learners" (p. 292). In a similar vein, Morales and Smith (2008) advise the teachers of Spanish and other languages to encourage their students to use the strategies that are more associated with successful language learning.

The study revealed that the perceptions of language teachers and learners are partly but not fully similar. In fact, there existed some broad consensus on many of the characteristics mentioned by both groups but not on all the characteristics. This reflects the different ways that the groups approach the task of language learning which is potential to have its own consequences. For example, while teachers may be more keen on developing the students' communicative abilities, the students may be more inclined towards lower-level aspects of the language. As Norton and Toohey (2001) pointed out, "Our research and recent theoretical discussions have convinced us that understanding good language learning requires attention to social practices in the contexts in which individuals learn L2s" (p. 318).

The characteristics associated with successful and unsuccessful language learners by Iranian EFL learners suggest that they believe that the teacher's authority in the classroom setting is among the most important factors to distinguish good and poor language learners. This way of thinking is traditional in nature and relates to 
traditional settings of language learning as well. The other features mentioned show that EFL learners associate steady and frequent practice with good language learners and that a lack of such a feature is among the poor language learners' characteristics. In addition, since lack of interest in the target language was stated by the participants as one of the most significant features of unsuccessful language learners, then the language teachers are expected to motivate the learners in learning the target language. Furthermore, the mismatch in the beliefs of these two participant groups can lead to unfavorable results in the academic context. Language teachers are expected to provide EFL learners with correct ideas and beliefs as to who is labeled a successful or unsuccessful language learner.

Note: This paper was presented at the National Conference on Language, Teaching and Literature (LTL) held by Malayer University, Malayer, Iran, under the title of "Who are good and poor language learners: EFL teachers' vs. learners' perceptions", on May $2^{\text {nd }}, 2013$.

\section{References:}

Akbari, R., \& Hosseini, K. (2008). Multiple intelligences and language learning strategies: Investigating possible relations. System, 36, 141-155. http://dx.doi.org/10.1016/j.system.2007.09.008

Alves, A. R. (2008). The good language learner. The University of Birmingham.

Amiri, M., \& Baghchejoughi, K. J. (2011). Good language learners' qualifications and social promotion: a case study in the Iranian context. European Journal of Scientific Research, 58(2), 285-295.

Dörnyei, Z. (2005). The psychology of the language learner. USA: Lawrence Erlbaulm Associates, Inc. Publishers.

Gu, P. Y. (2003). Fine brush and freehand: The vocabulary-learning art of two successful Chinese EFL learners. TESOL Quarterly, 37(1), 73-104. http://dx.doi.org/10.2307/3588466

Halbakh, A. (2000). Finding out about students' learning strategies by looking at their diaries: a case study. System, 28, 85-96. http://dx.doi.org/10.1016/S0346-251X(99)00062-7

Ho, G. A. L. (2011). Understanding good language learners of Vietnamese as a foreign language. Electronic Journal of Foreign Language Teaching, 8(2), 385-398.

Kuhi, D., \& Abdolvash, M. (2014). Azerbaijani Turkic speaking English language teachers' attitudes towards the use of their students' mother tongue in English classes. International Journal of Research Studies in Language Learning, 3(3), 55-72. http://dx.doi.org/10.5861/ijrsll.2013.553

Maftoon, P., Daftarifard, M., \& Lavasani, M. (2011). Good language learner: From autonomy perspective. LiBRI, 2(1), 104-114.

Morales, M., \& Smith, D. J. (2008). Spanish learning strategies of some good language learners. PORTA LINGUARUM, 9, 167-177.

Naiman, N., Frohlich, M., Stern, H. H., \& Toedesco, A. (1978). The good language learner. Toronto: Ontario Institute for Studies in Education (OISE).

Norton, B., \& Toohey, K. (2001). Changing perspectives on good language learners. TESOL Quarterly, 35(2), 307-322. http://dx.doi.org/10.2307/3587650

Rubin, J. (1975). What the 'good language learner' can teach us. TESOL Quarterly, 9(1), 41-51. http://dx.doi.org/10.2307/3586011

Stern, H. H. (1990). Fundamental concepts of language teaching. Oxford: Oxford University Press.

Takeuchi, O. (2003). What can we learn from good foreign language learners? A qualitative study in the Japanese foreign language context. System, 31, 382-392. http://dx.doi.org/10.1016/S0346-251X(03)00049-6 